\title{
In vivo Antioxidant Activity of Dregea volubilis Linn. on Chromium (vi)-Induced Oxidative Stress in Albino Rats
}

\author{
Venkatesan Natarajan*, Vishwanath BA
}

\section{Venkatesan Natarajan ${ }^{1, *}$,} Vishwanath $\mathrm{BA}^{2}$

'Department of Pharmacology, Adiya Bangalore Institute of Pharmacy Education and Research, Bangalore, Karnataka, INDIA.

${ }^{2}$ Department of Pharmaceutics, Adiya Bangalore Institute of Pharmacy Education and Research, Bangalore, Karnataka, INDIA.

\section{Correspondence}

Dr. Venkatesan Natarajan

Professor, Department of Pharmacology, Adiya Bangalore Institute of Pharmacy Education and Research,

Bangalore-560064, Karnataka, INDIA.

E-mail: venkatcology@gmail.com

History

- Submission Date: 20-09-2021;

- Review completed: 21-10-2021;

- Accepted Date: 07-12-2021.

DOI : 10.5530/fra.2021.2.9

Article Available online

http://www.antiox.org

\section{Copyright}

(C) 2021 Phcog.Net. This is an openaccess article distributed under the terms of the Creative Commons Attribution 4.0 International license.

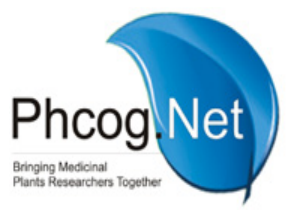

\begin{abstract}
Objectives: To evaluate the in vivo antioxidant potential of various extracts of Dregea volubilis on chromium (VI)-induced oxidative stress in albino rats. Methods: Animals were treated with plant extracts for 28 days and then oxidative stress was induced with a single doses of Chromium 30mg/kg (p.o.). Treated with $200 \mathrm{mg} / \mathrm{kg}$ (p.o.) of alcoholic extract of Dregea volubilis and determine the glutathione, SOD, catalase, peroxidise and transaminase enzymes levels. Results: The present studies revealed that Dregea volubilis has significant in vivo antioxidant activity and can be used to protect tissue from oxidative stress. The result showed that the activities of glutathione, SOD, catalase and peroxidise and tranaminase enzymes in group treated with chromium (VI) declined significantly than that of compared with control group. Conclusion: Ethanolic extract of Dregea volubilis in the dose of $200 \mathrm{mg} / \mathrm{kg}$, p.o., has improved the glutathione, SOD, catalase, and peroxidase and transaminase enzymes levels significantly, which were comparable with Vitamin-E. Based on this study we conclude that Alcoholic extract of Dregea volubilis possesses in vivo antioxidant activity and can be employed in protecting tissue from oxidative stress.

Key words: Dregea volubilis, In vivo Antioxidant activity, Chromium (VI), Vitamin-E, Free radicals, Oxidative stress.
\end{abstract}

\section{INTRODUCTION}

Dregea volubilis Linn (Family: Asclepiadaceae) is widely used in Indian traditional medicines and the leaf paste is used to treat rheumatic pain, cough, fever and severe cold. ${ }^{1,2}$ Leaf paste is taken along with pepper to treat dyspepsia, ${ }^{3}$ Bark paste, mixed with hot milk is used internally for treating urinary infections. ${ }^{4}$ Traditionally, leaves are used as an application to boils and abscesses. The plant is being used very specifically in the indigenous systems of medicine such as Ayurveda, Siddha and Unani. Plants still represent a large untapped source of structurally novel compounds that might serve as lead for the development of novel drugs. ${ }^{5}$ The formation of reactive oxygen species (ROS) / free radicals is a naturally occurring intracellular metabolic process. These harmful species are known to cause oxidative damage to a number of molecules in cells including membrane lipids, proteins and nucleic acids. The potential harmful effects of these species are controlled by the cellular antioxidant defense system. ${ }^{6}$ In recent years, the chemical importance of the herbal drugs has received considerable attention as many synthetic antioxidants have been shown to have one or the other side effects. There has been an upsurge of interest in the therapeutic potential; of the medicinal plants as antioxidants in reducing free radicals induced tissue injury. Numerous plant products have been shown to have the antioxidant activity and the antioxidant vitamins, flavonoids and polyphenolic compounds of the plant origin have been extensively reported as scavengers of free radicals and inhibitors of the lipid peroxidation. ${ }^{7}$ Hence in the present study was planned to determine the antioxidant activity or potential of the plant by inducing the free radicals in the animal model with the help of chromium (VI).

\section{MATERIALS AND METHODS}

\section{Plant materials}

Whole fresh plant leaves of Dregea volubilis were collected from kalakatu, Tirunelveli District, India. Taxonomic identification was made from botanical survey of medicinal plants, Siddha Unit, Government of India, Palayamkottai. The whole plant leaves were dried under shade, segregated, pulverized by a mechanical grinder and passed through a 40 mesh sieve.

\section{Preparation of Extracts}

The above powdered materials $(1 \mathrm{~kg})$ were successively extracted with petroleum ether $\left(40-60^{\circ} \mathrm{C}\right)$, ethyl acetate $\left(40-60^{\circ} \mathrm{C}\right)$ and ethanol $\left(70-80^{\circ} \mathrm{C}\right)$ for $48 \mathrm{hr}$ by continuous hot percolation method in soxhlet apparatus. ${ }^{8}$ The extract was collected and evaporated to dryness by using a vacuum distillation unit. The dried extracts were stored in airtight container. 


\section{Preliminary Phytochemical Screening}

The preliminary phytochemical screening was carried out with ethanolic extracts of Dregea volubilis leaves for the detection of various phytochemicals. Tests for common phytochemicals were carried out by standard methods. ${ }^{9}$

\section{Animals}

Male albino wistar rats each weighing 180-220 were obtained from Aditya Bangalore Institute of Pharmacy Education and Research in Bangalore. Rodent laboratory chow was access and water ad libitum, and rats were maintained on a $12 \mathrm{hr}$ light/dark cycle in a temperature regulated room $\left(20-25^{\circ} \mathrm{C}\right)$ during the experimental procedures. The animals were cared for according to the guiding principles in the care and use of animals.

\section{Acute toxicity test}

Acute toxicity tests were performed according to OECD - 423 guidelines. ${ }^{10}$ Albino rats $(n=6)$ of either sex selected by random sampling technique were employed in this study. The animals were fasted for $4 \mathrm{hr}$ with free access to water only. The ethanolic extract of Dregea volubilis suspended in normal saline: Tween 80 (95:5) was administered orally at a dose of $5 \mathrm{mg} / \mathrm{kg}$ initially and mortality was observed for 3 days. The mortality was observed in 5/6 or 6/6 animals, and then the dose administered was considered as toxic dose. However, the mortality was observed in less than four rats, out of six animals then the same dose was repeated again to confirm the toxic effect. The mortality was not observed, the procedure was then repeated with higher doses such as 100, 300 and $1500 \mathrm{mg} / \mathrm{kg}$.

\section{Experimental Design}

Rats were divided randomly into six groups of six animals each and treated for four weeks i.e. 28 days as follows: Group I animals served as normal control group received normal saline in a dose of $10 \mathrm{ml} / \mathrm{kg}$. Group II served as toxic control group and was administered chromium $30 \mathrm{mg} / \mathrm{kg}(30 \% \mathrm{~V} / \mathrm{V}, 1-0 \mathrm{ml} / 100 \mathrm{~kg})$ orally. ${ }^{11}$ Group III served as a standard group and was administered Vitamin E in a dose of $200 \mathrm{mg} / \mathrm{kg}$ orally. ${ }^{12}$ Group IV served as a treatment control group and was administered Pet. ether extract of Dregea volubilis (PEDV) in a dose of $200 \mathrm{mg} / \mathrm{kg}$ orally. (As per OECD guidelines $\mathrm{LD}_{50}$ value). Group V served as a treatment control group and was administered ethyl acetate extract of Dregea volubilis (EEDV) in a dose of $200 \mathrm{mg} / \mathrm{kg}$ orally. Group VI served as a treatment control group and was administered ethanolic extract of Dregea volubilis (AEDV) in a dose of $200 \mathrm{mg} / \mathrm{kg}$ orally. Group III to VI was given the Vitamin E and three extracts of Dregea volubilis one hour prior to the administration of the chromium (VI).

\section{Biochemical Analysis}

\section{Dissection and Homogenization}

On the $29^{\text {th }}$ day all animal were killed by decapitation. Blood was collected and serum was separated for estimation of alanine aminotransferase (ALT) and aspartate aminotranferase (AST). ${ }^{13}$ The liver was rapidly excised rinsed in ice-cold saline and a $10 \% \mathrm{~W} / \mathrm{V}$ homogenate was prepared using $(0.15 \mathrm{MKCl})$ potassium chloride. Centrifuged at $800 \mathrm{rpm}$ for $10 \mathrm{~min}$ at $4^{\circ} \mathrm{C}$. The supernatant obtained was used for the estimation of catalase, and lipid per oxidation. Further the homogenate was centrifuged at $1000 \mathrm{rpm}$ for $20 \mathrm{~min}$ at $4^{\circ} \mathrm{C}$ and the supernatant was used for estimation of SOD and glutathione.

\section{Lipid Per Oxidation Assay (LPO)}

Malondialdehyde (MDA), a secondary product of lipid per oxidation reacts with thiobarbituric acid at $\mathrm{pH}$ 3.5. The red pigment produced was extracted in n-butanol-pyridine mixture and estimated by measuring the absorbance at $532 \mathrm{~nm} .^{14}$

\section{Superoxide dismutase activity (SOD)}

Superoxide dismutase activity was assayed according to the method of kono, ${ }^{15}$ where in the reduction of nitro blue tetrazolium chloride (NBT) was inhibited by superoxide dismutase and measured at $560 \mathrm{~nm}$ spectrophotometrically. Briefly the reaction was initiated by addition of hydroxylamine hydrochloride to the reaction mixture containing NBT and post nuclear fraction of liver homogenate. The results were expressed as units per milligram of protein with one unit of enzyme defined as the amount of SOD required to inhibit the rate of reaction by $50 \%$.

\section{Catalase activity (CAT)}

Catalase activity was assessed by the method of luck, ${ }^{16}$ where the breakdown of $\mathrm{H}_{2} \mathrm{O}_{2}$ was measured at $240 \mathrm{~nm}$. Briefly the assay mixture consisted of $3 \mathrm{ml}$ of $\mathrm{H}_{2} \mathrm{O}_{2}$ phosphate buffer $\left(0.0125 \mathrm{M} ; \mathrm{H}_{2} \mathrm{O}_{2}\right)$ and $0.05 \mathrm{ml}$ of supernatant of liver homogenate and the change in the absorbance was measured at $240 \mathrm{~nm}$. The enzyme activity was calculated using the mill molar extension coefficient of $\mathrm{H}_{2} \mathrm{O}_{2}(0.07)$. The results were expressed as micromole of $\mathrm{H}_{2} \mathrm{O}_{2}$ decomposed per min per milligram of protein.

\section{Estimation of Reduced Glutathione}

Reduced glutathione (GSH) in the liver was assayed according to the method of Ellman. ${ }^{17}$ Sample $(0.75 \mathrm{ml})$ of homogenate was precipitated with $0.75 \mathrm{ml}$ of $4 \%$ sulphosalicyclic acid and centrifuged at $1200 \mathrm{~g}$ for $15 \mathrm{~min}$ at $4^{\circ} \mathrm{C}$. The assay mixture contained $0.5 \mathrm{ml}$ of supernatant and $4.5 \mathrm{ml}$ of $0.01 \mathrm{M}$, DTNB. (5-5'-dithiobis (2-nitro benzoic acid)) in $0.1 \mathrm{M}$, phosphate buffer ( $\mathrm{PH} 8.0$ ). The yellow colour developed was read immediately at $412 \mathrm{~nm}$. The results were expressed as micromole of GSH per milligram of proteins.

\section{Determination of AST (Aspartate aminotransferase) and ALT (Alanine aminotransferase)}

AST (aspartate aminotransferase) and ALT (Alanine aminotransferase) from the liver in the blood serum was assayed according to the method of Reitman'S, Frankel S. ${ }^{18}$

\section{Statistical Analysis}

The results are expressed as mean \pm SEM. Data was evaluated using one way ANOVA followed by Newman Keul's multiple range test. Probability values less than $(P<0.01)$ were considered significant.

\section{RESULTS}

\section{Effect of various extracts of Dregea volubilis on SOD and Catalase levels}

Administration of chromium caused a significant increase $(p<0.01)$ in the liver tissue catalase levels but did not affect SOD levels (Table 1). The AEDV in a dose of each $200 \mathrm{mg} / \mathrm{kg}$ body weight was able to restore the catalase levels significantly to that of control values. But the animlas treated with PEDV and EEDV did not change catalase levels significantly.

\section{Effect of various extracts of Dregea volubilis on Reduced GSH and MDA (Lipid peroxidation)}

Liver tissue GSH levels were significantly decreased following the chromium treatment, where as significant increase in plasma MDA levels was observed respectively (Table 1). Administration of AEDV in a dose of $200 \mathrm{mg} / \mathrm{kg}$ body weight, reverted the GSH and MDA levels to that of control values. But the animals treated with PEDV and EEDV did not change GSH and MDA levels significantly.

Effect of various extracts of Dregea volubilis on AST and 
Table 1: Effect of Various extracts of Dregea volubilis on chromium induced free radicals in rats.

\begin{tabular}{|c|c|c|c|c|c|c|}
\hline Groups & $\begin{array}{l}\text { SOD } \\
\text { U/L }\end{array}$ & $\begin{array}{c}\text { CATALASE } \\
\mathrm{min} / \mathrm{mg} \text { of protein }\end{array}$ & $\begin{array}{c}\text { REDUCED } \\
\text { GSH } \\
\mathrm{mg} / \mathrm{dl}\end{array}$ & $\begin{array}{c}\text { LIPID } \\
\text { PEROXIDATION } \\
\text { nmoles } / \mathrm{ml}\end{array}$ & $\begin{array}{l}\text { AST } \\
\text { U/L }\end{array}$ & $\begin{array}{l}\text { ALT } \\
\text { U/L }\end{array}$ \\
\hline Group-I & $33.78 \pm 1.42$ & $280.6 \pm 4.60$ & $120.26 \pm 2.75$ & $176.25 \pm 2.48$ & $196.22 \pm 3.10$ & $90.88 \pm 2.24$ \\
\hline Group-II & $30.42 \pm 1.16$ & $182.45 \pm 2.48^{\star} a$ & $63.26 \pm 1.24^{*} \mathrm{a}$ & $265.40 \pm 5.27 * a$ & $336.24 \pm 6.2^{*} \mathrm{a}$ & $222.92 \pm 3.15^{\star} a$ \\
\hline Group-III & $28.46 \pm 1.78$ & $242.85 \pm 4.30 * b$ & $96.8 \pm 1.96^{*} \mathrm{~b}$ & $190.8 \pm 4.19^{*} b$ & $240.22 \pm 3.95^{\star} \mathrm{b}$ & $132.55 \pm 3.45^{\star} b$ \\
\hline Group-IV & $32.12 \pm 1.90$ & $195.10 \pm 2.50$ & $70.24 \pm 2.20$ & $255.12 \pm 5.42$ & $324.16 \pm 6.05$ & $215.14 \pm 3.48$ \\
\hline Group-V & $32.42 \pm 1.36$ & $188.25 \pm 2.28$ & $68.22 \pm 2.10$ & $249.78 \pm 5.23$ & $318.15 \pm 5.70$ & $220.72 \pm 3.78$ \\
\hline Group-VI & $32.20 \pm 1.48$ & $222.30 \pm 3.28^{\star} b$ & $89.88 \pm 3.26^{\star} b$ & $203.42 \pm 4.28^{\star} \mathrm{b}$ & $258.45 \pm 3.22 * b$ & $153.23 \pm 2.62 * b$ \\
\hline
\end{tabular}

Values are expressed as mean \pm SEM.

- Values were find out by using one way ANOVA followed by Newman Keul's multiple range test.

- $\quad\left(\mathrm{a}^{*}\right)$ values were significantly different from Normal control $(\mathrm{G} 1)$ at $(P<0.01)$.

- $\left(b^{* *}\right)$ values were significantly different from toxic group $(G 2)$ at $(P<0.01)$.

\section{ALT levels}

AST and ALT levels were increased $(p<0.01)$ in all the animals treated with chromium (Table 1). Administration of $200 \mathrm{mg} / \mathrm{kg}$ body weight dose of AEDV significantly inhibited the chromium induced increase in enzyme levels and restored to that of control values. But the animals treated with PEDV and EEDV did not change AST and ALT levels significantly.

\section{DISCUSSION}

One of the most important early events in cell degeneration leading to necrosis is the Lipid peroxidative damage that occurs mainly in the cell membrane. In addition, lipid peroxidation represents one of the most reaction resulting from free radicals attack on biological structures $\mathrm{Cr}(\mathrm{VI})$ and $\mathrm{Cr}(\mathrm{V})$ are both able to yield ROS. ${ }^{19}$ The majority of oxidative stress studies in rat have used TBARS as a tissue damage indicator. ${ }^{20}$ In addition there was no study relating various extracts of Dregea volubilis with chromium intoxication. Therefore in this study was undertaken to evaluate for the antioxidant activity against the chromium (VI) induced oxidative stress in male albino rats. The results of the present study demonstrate that various extracts of Dregea volubilis at a dose of $200 \mathrm{mg} / \mathrm{kg}$ body weight protected the animals significantly from the chromium induced oxidative damage. Oral feeding of chromium resulted in a significant decrease in body weight. Chromium (IV) Compounds are well known oxidizing agents capable of directly inducing tissue damage and possess carcinogenic, mutagenic and teratogenic potency ${ }^{21}$ Chromium (VI) compounds are easily taken up by cells and are subsequently reduced to $\mathrm{Cr}$ (III) species. This reduction generates free radicals, which play major role in the adverse biological effect of these compounds. ${ }^{22}$ Administration of chromium significantly increases the lipid peroxidation as evident by the increase in MDA levels. To cope with the oxidative stress, there was a significant decrease in reduced glutathione (GSH) and catalase level in the liver tissue. No significant change in the SOD activity was observed in the Chromium-treated animals and our results fall in confirmation with earlier studies. ${ }^{23}$ Besides activating the oxidative stress, Chromium also caused a marked increase in AST and ALT levels suggesting that the Chromium treatment also causes hepatic damage. Many workers have also demonstrated the hepato-toxic effect of Chromium (VI), ${ }^{24}$ which is mainly due to the lipid peroxidation. These adverse effects of Chromium (VI) could be significantly curtailed by pre treating the animals with the AEDV.
In animals fed with Alcoholic extracts of Dregea volubilis significant protection was observed against the chromium induced oxidative stress. The Alcoholic extracts of Dregea volubilis inhibited the chromium induced increase in MDA levels and restore the intracellular antioxidant, Like GSH and catalase levels to that control. The Alcoholic extracts of Dregea volubilis also protected the animals significantly from the hepatotoxicity induced by chromium is revealed by the decreased AST and ALT activity compared to the chromium (VI) treated animals.

\section{CONCLUSION}

In conclusion of our studies revealed that alcoholic extract of Dregea volubilis have significant antioxidant activities as compared with standard group of Vitamin E.

\section{ACKNOWLEDGEMENT}

This study was carried out in the Aditya Bangalore Institute of Pharmacy Education and Research, Bangalore. We would like to thank the institution for providing the Lab facilities required for this study.

\section{CONFLICT OF INTERSEST}

The authors declare no conflict of interest.

\section{REFERENCES}

1. Muthu C, Ayyanar M, Raja N, Ignacimuthu S. Medicinal plants used by traditional healers in Kancheepuram District of Tamil Nadu, India. J Ethnobiol Ethnomed. 2006;2:43. doi: 10.1186/1746-4269-2-43, PMID 17026769.

2. Rajadurai M, Vidhya VG, Ramya M, BhaskarA. Ethno-Medicinal plants used by the Traditional Healers of Pacchamalai Hills, Tamil Nadu, India. J Ethnobiol Ethnomed. 2009;3:39-41.

3. Pandikumar $P$, Ayyanar M, Ignacimuthu S. Medicinal plants used by Malasar tribes of Coimbatore district, Tamil Nadu. Ind J Trad Knowl. 2007;6:579-82.

4. Natarajan V, Arul Gnana Dhas AS. Effect of active fraction isolated from the leaf extract of Dregea volubilis [Linn.] Benth. on plasma glucose concentration and lipid profile in streptozotocin-induced diabetic rats. Springerplus. 2013;2:394. doi: 10.1186/2193-1801-2-394. PMID 24010048.

5. Cowan MM. Plant products as antimicrobial agents. Clin Microbiol Rev. 1999;12(4):564-82. doi: 10.1128/CMR.12.4.564. PMID 10515903.

6. Husain K, Scott BR, Reddy SK, Somani SM. Chronic ethanol and nicotine interaction on rat tissue antioxidant defense system. Alcohol. 2001;25(2):89-97. doi: 10.1016/s0741-8329(01)00176-8, PMID 11747978.

7. Geetha S, Sai Ram M, Mongia SS, Singh V, Ilavazhagan G, Sawhney RC. Evaluation of antioxidant activity of leaf extract of Seabuckthorn (Hippophae rhamnoides L.) on chromium (VI) induced oxidative stress in albino rats. Ethnopharmacol. 2003;87(2-3):247-51. doi: 10.1016/s0378-8741(03)00154-5, 
PMID 12860317

8. Bagchi D, Stohs SJ, Downs BW, Bagchi M, Preuss HG. Cytotoxicity and oxidative mechanisms of different forms of chromium. Toxicology. 2002;180(1):5-22. doi: 10.1016/s0300-483x(02)00378-5, PMID 12324196.

9. Bagchi D, Vuchetich PJ, Bagchi M, Hassoun EA, Tran MX, Tang L, et al. Induction of oxidative stress by chronic administration of sodium dichromate [chromium VI] and cadmium chloride [cadmium II] to rats. Free Radic Biol Med. 1997;22(3):471-8. doi: 10.1016/s0891-5849(96)00352-8, PMID 8981039.

10. Léonard A, Geber GB, Jacquet P, Lauwerys RR. Carcinogenicity, mutagenicity, and teratogenicity of industrially used metals. In: Kirsch-Volders $M$, editor, Mutagenicity, carcinogenicity, and teratogenicity of industrial pollutants. New York: Plenum Press; 1994;123-45.

11. Danielsson BR, Hassoun $E$, Dencker L. Embryo toxicity of chromium: Distribution in pregnant mice and effects on embryonic cells in vitro. Arch Toxicol. 1982;51:233-45.

12. Kawanishi S, Inoue S, Sano S. Mechanism of DNA cleavage induced by sodium chromate $(\mathrm{VI})$ in the presence of hydrogen peroxide. J Biol Chem. 1986;261(13):5952-58. doi: 10.1016/S0021-9258(17)38476-4, PMID 3009436.

13. Harbone JB. Phytochemical methods. 2nd ed. Chapman and Hall: New York; 1984.

14. Jones P, Kortenkamp A, O'Brien P, Wang G, Yang G. Evidence for the generation of hydroxyl radicals from a chromium(V) intermediate isolated from the reaction of chromate with glutathione. Arch Biochem Biophys. 1991;286(2):652-5. doi: 10.1016/0003-9861(91)90095-z, PMID 1654797.

15. Nade VS, Dwivedi S, Kawale LA, Upasani CD, Yadav AV. Effect of Hibiscus rosa sinensis on reserpine-induced neurobehavioral and biochemical alterations in rats. Indian J Exp Biol. 2009;47(7):559-63. PMID 19761039.
16. Joharapurkar AA, Zambad SP, Wanjari MM, Umathe SN. In vivo evaluation of antioxidant activity of alcohol extract of Rubia cordifolia linn and its influence on ethanol induced immunosuppression. Indian J Pharmacol. 2003;35:232-6.

17. P, Li K, Jin Y, Song F, Zhou S, Sun X, Nüssler AK, Liu L. Oxidative damage after chronic ethanol intake in rat tissues: Prophylaxis of Ginkgo biloba extract. Food Chem. 2006;99(2):305-14. doi: 10.1016/j.foodchem.2005.07.047.

18. Tayal V, Kalra BS, Agarwal S, Khurana N, Gupta U. Hepatoprotective effect of tocopherol against isoniazid and rifampicin induced hepatotoxicity in albino rabbits. Indian J Exp Biol. 2007;45(12):1031-6. PMID 18254208.

19. Sundaram R, Mitra SR. Antioxidant activity of ethyl acetate soluble fraction of Acacia arabica bark in rats. Indian J Pharmacol. 2007;39(1):33-8.

20. Ohkawa H, Ohishi N, Yagi K. Assay for lipid peroxides in animal tissues by thiobarbituric acid reaction. Anal Biochem. 1979;95(2):351-8. doi: 10.1016/00032697(79)90738-3, PMID 36810

21. Kono Y. Generation of superoxide radical during autoxidation of hydroxylamine and an assay for superoxide dismutase. Arch Biochem Biophys. 1978;186(1):189-95. doi: 10.1016/0003-9861(78)90479-4.

22. Luck H. Catalase in methods of enzymatic Analaysis. New York: Academic press; 1971;885.

23. Ueno S, Susa N, Furukawa $Y$, Sugiyama M. Formation of Paramagnetic chromium in liver of mice treated with dichromate (VI). Toxicol Appl Pharmacol. 1995;135(2):165-71. doi: 10.1006/taap.1995.1219, PMID 8545823.

24. Dartsch PC, Hildenbrand S, Kimmel R, Schmahl FW. Investigations on the nephrotoxicity and hepatotoxicity of trivalent and hexavalent chromium compounds. Int Arch Occup Environ Health. 1998;71;Suppl:S40-5. PMID 9827879 .

Cite this article: Natarajan V, Vishwanath BA. In vivo Antioxidant Activity of Dregea volubilis Linn on Chromium (vi)-Induced Oxidative Stress in Albino Rats. Free Radicals and Antioxidants. 2021;11(2):38-41. 